\title{
Therapy-related Myeloid Leukemia With the Translocation t(8;19)(p11;q13) Leading to a KAT6A-LEUTX Fusion Gene
}

\author{
IOANNIS PANAGOPOULOS ${ }^{1}$, KRISTIN ANDERSEN ${ }^{1}$, LLOYD FRODE RAMSLIEN ${ }^{2}$, \\ IDA MÜNSTER IKONOMOU ${ }^{3}$, FRANCESCA MICCI ${ }^{1}$ and SVERRE HEIM ${ }^{1,4}$ \\ ${ }^{1}$ Section for Cancer Cytogenetics, Institute for Cancer Genetics and Informatics, \\ The Norwegian Radium Hospital, Oslo University Hospital, Oslo, Norway; \\ ${ }^{2}$ Department of Cancer and Hematological Diseases, Telemark Hospital, Skien, Norway; \\ ${ }^{3}$ Department of Pathology, Oslo University Hospital, Oslo, Norway; \\ ${ }^{4}$ Institute of Clinical Medicine, Faculty of Medicine, University of Oslo, Oslo, Norway
}

\begin{abstract}
Background/Aim: The chromosome translocation $t(8 ; 19)(p 11 ; q 13)$ has been reported in only six acute myeloid leukemia (AML) patients. We here present the genetic and clinical features of the seventh AML case with this aberration. Materials and Methods: Cytogenetic and molecular genetic investigations were performed on leukemic bone marrow cells from a patient with therapy-related AML. Results: A $t(8 ; 19)($ p11;q13) was found leading to an in-frame fusion of exon 16 of the lysine acetyltransferase $6 A$ gene (KAT6A) from $8 p 11$ with exon 2 of the leucine twenty homeobox gene (LEUTX) from 19q13 resulting in expression of the otherwise silent LEUTX gene in the leukemic cells. The KAT6A-LEUTX protein is predicted to act as a histone acetyltransferase at its amino-terminal-KAT6A moiety but as a homeobox transcription factor at the LEUTX-carboxyl-terminal moiety. Conclusion: The present case is the second therapy-related $A M L$, and the third $A M L$ overall, in which both a t(8;19)(p11;q13) and its molecular result, a KAT6A-LEUTX fusion gene, are described. The t(8;19)(p11;q13)/KAT6A-LEUTX deregulates transcription and induces leukemogenesis.
\end{abstract}

The chromosome translocation $\mathrm{t}(8 ; 19)(\mathrm{p} 11 ; \mathrm{q} 13)$ was first described in 1988 in an eight-month-old male infant with AML [French-American-British (FAB) classification M5a] in whom

This article is freely accessible online.

Correspondence to: Ioannis Panagopoulos, Section for Cancer Cytogenetics, Institute for Cancer Genetics and Informatics, The Norwegian Radium Hospital, Oslo University Hospital, P.O. Box 4953 Nydalen, NO-0424 Oslo, Norway. Tel: +47 22934424, e-mail: ioannis.panagopoulos@rr-research.no

Key Words: Acute myeloid leukemia, chromosome translocation, $\mathrm{t}(8 ; 19)(\mathrm{p} 11 ; \mathrm{q} 13)$, fusion gene, KAT6A, LEUTX, KAT6A-LEUTX, histone acetyltransferase, homeobox gene. the leukemic cells displayed prominent erythrophagocytosis (1). Until now, $\mathrm{t}(8 ; 19)(\mathrm{p} 11 ; \mathrm{q} 13)$ has been reported in only six patients with AML and FAB type M5 or M4 (1-7) (Table I). In a therapy-related AML M4 and in a recently reported newborn with AML, the translocation was shown to fuse the lysine acetyltransferase 6A gene (KAT6A, also known as $M O Z$ and MYST3) from 8p11 with the leucine twenty homeobox gene (LEUTX) from 19q13 $(1,2,5)$. Because of the rarity of AML carrying a $\mathrm{t}(8 ; 19)(\mathrm{p} 11 ; \mathrm{q} 13) / K A T 6 A-L E U T X$, we here present the genetic and clinical feature of a therapy-related AML with $\mathrm{t}(8 ; 19)(\mathrm{p} 11 ; \mathrm{q} 13)$ and KAT6A-LEUTX fusion.

\section{Materials and Methods}

Ethics statement. The study was approved by the regional ethics committee (Regional komité for medisinsk forskningsetikk Sør-Øst, Norge; 2010/1389/REK sør- $\varnothing s t ~ A)$, and written informed consent was obtained from the patient. All patient information has been anonymized.

Case report. The patient was a seventy-year-old female who had had locally advanced cancer of the uterine cervix for which she had received radiation therapy and cisplatin with curative intent, with cessation of treatment one year prior to the diagnosis of AML. At the time when AML was diagnosed, the patient was suffering from fatigue, dyspnea, headaches, and loss of appetite, functioning in Eastern Cooperative Oncology Group (ECOG) performance status 1. The blood counts and other laboratory analyses showed: Hemoglobin $7.1 \mathrm{~g} / \mathrm{dl}$, Leukocytes $0.6 \times 10^{9} / 1$, Neutrophils $0.1 \times 10^{9} / 1$, Lymphocytes $0.5 \times 10^{9} / 1$, Monocytes $0.0 \times 10^{9} / 1$, Eosinophils $0.0 \times 10^{9} / 1$, Basophils $0.0 \times 10^{9} / 1$, Thrombocytes $26 \times 10^{9} / 1$, Creatinine $95 \mu \mathrm{mol} / \mathrm{l}$, GFR 52, LD $372 \mathrm{U} / \mathrm{l}$, and Ferritin $2010 \mu \mathrm{g} / \mathrm{l}$. The peripheral blood smear revealed anisocytosis, thrombocytopenia, and neutropenia. There were $2 \%$ large myeloblasts. The few neutrophils seen showed no evidence of dysplasia.

The marrow aspirate showed very low cellularity, few megakaryocytes, $3 \%$ erythroid precursors, lymphocytes $37 \%$, monocytes $3 \%$, and reduced granulocytopoiesis (20\%) with almost all precursors being promyelocytes. The blast cells (33\%) were large and cytoplasm rich with vacuoles in both the cytoplasm and 
Table I. The published acute myeloid leukemias (AML) with their French-American-British (FAB) classification carrying a t(8;19)(p11;q13) chromosome translocation.

\begin{tabular}{|c|c|c|c|c|c|c|}
\hline Gender/Age & Diagnosis & $\begin{array}{l}\text { FAB } \\
\text { type }\end{array}$ & $\begin{array}{l}\text { Reported karyotype/ } \\
\text { Fusion gene }\end{array}$ & AML treatment & Clinical outcome & Reference (case) \\
\hline $\mathrm{M} / 8$ months & de novo $\mathrm{AML}$ & M5a & $\begin{array}{c}46, \mathrm{XY}, \mathrm{t}(8 ; 19)(\mathrm{p} 11 ; \mathrm{q} 13.2) \\
{[8] / 46, \mathrm{XY}, \mathrm{t}(8 ; 19)} \\
-1,+1 \mathrm{q}+[22] / 46, \mathrm{XY}, \mathrm{t} \\
(8 ; 19),-16,+16 \mathrm{q}+[6]\end{array}$ & $\begin{array}{l}\text { Chemotherapy followed } \\
\text { by bone marrow } \\
\text { transplantation } \\
\text { diseases }\end{array}$ & $\begin{array}{l}\text { Death ( } 3.5 \text { months } \\
\text { after diagnosis) due } \\
\text { to veno-occlusive }\end{array}$ & $\begin{array}{l}\text { Brizard et al. } \\
\text { (1988) (case 3) }\end{array}$ \\
\hline F/15.5-year-old & de novo $\mathrm{AML}$ & M4 & $\begin{array}{c}46, \mathrm{XX}, \mathrm{t}(8 ; 19)(\mathrm{p} 11 ; \mathrm{q} 13)[6] \\
/ 46, \mathrm{XX}[15]\end{array}$ & Chemotherapy & Remission (14 months) & $\begin{array}{l}\text { Stark et al. } \\
\quad \text { (1995) }\end{array}$ \\
\hline M/76-year-old & de novo $\mathrm{AML}$ & M5a & $\begin{array}{c}46, \mathrm{XY}, \mathrm{t}(8 ; 19)(\mathrm{p} 11 ; \mathrm{q} 13.3) \\
{[18] / 46, \mathrm{XY}[2]}\end{array}$ & Chemotherapy & Remission (8 months) & $\begin{array}{l}\text { Gervais } \text { et al. } \\
\text { (2008) case } 29\end{array}$ \\
\hline M/71-year-old & $\begin{array}{c}\text { Secondary AML } \\
\text { (primary } \\
\text { malignancy: } \\
\text { non-Hodgkin } \\
\text { lymphoma }\end{array}$ & M4 & $\begin{array}{c}46, \mathrm{XY}, \mathrm{t}(8 ; 19)(\mathrm{p} 11 ; \mathrm{q} 13) \\
{[20] / K A T 6 A-L E U T X}\end{array}$ & Chemotherapy & $\begin{array}{l}\text { No response to therapy } \\
\text { Death (4 months after } \\
\text { AML diagnosis) due to } \\
\text { disease progression }\end{array}$ & $\begin{array}{l}\text { Chinen et al. } \\
\text { (2014) }\end{array}$ \\
\hline $\mathrm{F} / 3$ months & de novo $\mathrm{AML}$ & M4 & $\begin{array}{c}46, \mathrm{XX}, \mathrm{t}(8 ; 19)(\mathrm{p} 11.2 ; \mathrm{q} 13.3) \\
{[16] / 46, \mathrm{XX}[4] /} \\
\text { KAT6A aberration }\end{array}$ & Chemotherapy & Remission (24 months) & $\begin{array}{l}\text { Eason et al. } \\
\quad(2019)\end{array}$ \\
\hline F/16-day-old & Congenital AML & M5 & $\begin{array}{c}\text { 46,XX,t(8;19)(p11.2; } \\
\text { q13.3)/KAT6A-LEUTX }\end{array}$ & Chemotherapy & $\begin{array}{c}\text { Death (5 days after } \\
\text { diagnosis) }\end{array}$ & $\begin{array}{l}\text { Sramova et al. } \\
\quad(2020)\end{array}$ \\
\hline $\mathrm{F} / 70$ & Secondary AML & M5 & $\begin{array}{c}46, \mathrm{XX}, \mathrm{t}(8 ; 19)(\mathrm{p} 11.2 ; \\
\mathrm{q} 13.3)[10] / K A T 6 A-L E U T X\end{array}$ & & & Present case \\
\hline
\end{tabular}

nucleus. By flow cytometry, the cells expressed CD45, CD117, dim CD123, CD38, bright CD15, CD33, bright CD64, CD4, and partly myeloperoxidase (MPO), CD36 and HLA-DR, and showed unusually high and variable side scatter signals (SSC). Taken together, the findings were best compatible with AML of monocytic lineage [French-American-British (FAB)-classification M5], probably a therapy-related leukemia according to the WHO classification (8). Because of her prior radiation of the pelvis, no bone marrow biopsy was taken.

Because of her earlier treatment - which included cisplatin as well as radiation of the pelvis - and the very low bone marrow cellularity, the patient was not considered fit for intensive induction therapy, and she was given azacitidin and venetoclax. This treatment did not succeed in inducing remission, although her blood count improved and after two cycles, she became transfusion independent. The treatment has been well tolerated overall, in spite of complications in the form of hemorrhagic cystitis, reduced kidney function, and increased transaminase values that required a reduction of azacitidin and venetoclax doses.

The patient has at the time of writing received 6 courses of azacitidin and venetoclax. Her disease is stable; she has not achieved remission but neither are there signs of progression.

$G$-banding analysis. Bone marrow cells were short-term cultured and analyzed cytogenetically as previously described (9). Chromosome preparations were made from metaphase cells of a 24hour culture and G-banded using Leishman stain (Sigma-Aldrich; Merck Millipore, Darmstadt, Germany). Metaphases were analyzed and karyograms prepared using the CytoVision computer-assisted karyotyping system (Leica Biosystems, Newcastle, UK). The karyotypes were written according to the International System for Human Cytogenomic Nomenclature (10).
Molecular genetic analysis. Total RNA was extracted from the patient's bone marrow at diagnosis using the miRNeasy Mini Kit (Qiagen, Hilden, Germany). Complementary DNA (cDNA) was synthesized from one ng of total RNA using iScript Advanced cDNA Synthesis Kit for RT-qPCR according to the manufacturer's instructions (Bio-Rad, Hercules, California, USA). The quality of the cDNA synthesis was assessed by amplification of a cDNA fragment of the ABL protooncogene 1, non-receptor tyrosine kinase $(A B L 1)$ gene using the primer combination ABL1-91F1/ABL1404R1 (11).

For amplification of KAT6A-LEUTX cDNA fragments, nested PCR was performed. In the first, outer PCR assay, the $25 \mu \mathrm{l}$ reaction volume contained 12.5 $\mu \mathrm{l}$ of Premix Taq (Takara Bio Europe/SAS, Saint-Germain-en-Laye, France), $2 \mu \mathrm{l}$ of cDNA, and $0.4 \mu \mathrm{M}$ of each of the primers forward KAT6A-3558F1 (5'-TTG AAG ATT CTG ACT CCG AGA GGC-3') and reverse LEUTX-320R1 (5'-AGG GAG TCT CCT CCT TCT TCA CTG A-3'). PCR amplifications were run on a C-1000 Thermal cycler (Bio-Rad). Cycling included an initial denaturation at $94^{\circ} \mathrm{C}$ for $30 \mathrm{~s}$ followed by 35 cycles of $7 \mathrm{~s}$ at $98^{\circ} \mathrm{C}, 30 \mathrm{~s}$ at $60^{\circ} \mathrm{C}$, and $30 \mathrm{~s}$ at $72^{\circ} \mathrm{C}$ with a final extension for 5 $\min$ at $72^{\circ} \mathrm{C}$.

Three $\mu \mathrm{l}$ of the PCR products were stained with GelRed (Biotium, Hayward, CA, USA), analyzed by electrophoresis through $1.0 \%$ agarose gel, and photographed. DNA gel electrophoresis was performed using lithium borate buffer (12). The remaining $22 \mu \mathrm{l}$ PCR products were purified using the MinElute PCR purification kit (Qiagen). One $\mu \mathrm{l}$ was used as template in inner, nested PCR amplifications using the forward primer KAT6A-3582F1 (5'-CAA TGC CAA GAT TAG AAC CCA CGT-3') together with the reverse primer LEUTX-301R1 (5'-ACT GAA GTT GTC TGG TTT GCT GGC-3') and KAT6A-3582F1 together with LEUTX-157R1 (5'TTG TAG CCA AAC TTG GGT GCA TG-3'). PCR conditions and 
cycling were the same as for the first PCR. Three $\mu$ of the nested PCR products were analyzed by electrophoresis as described above. The remaining products of nested PCR were purified with the MinElute PCR purification kit (Qiagen) and direct sequenced using the BigDye Terminator v1.1 Cycle Sequencing Kit (ThermoFisher Scientifc) according to the manufacturer's instructions. Sequence analyses were performed on the Applied Biosystems SeqStudio Genetic Analyzer system (ThermoFisher Scientific). The basic local alignment search tool (BLAST) software was used for computer analysis of sequence data (13). The BLAT alignment tool and the human genome browser at University of California Santa Cruz (UCSC) were used to map the sequences on the Human GRCh37/hg19 assembly $(14,15)$.

\section{Results}

G-banding analysis of bone marrow cells at diagnosis yielded the karyotype 46,XX,t(8;19)(p11.2;q13.3)[10] (Figure 1A). PCR with the primer combination KAT6A3558F1/LEUTX-320R1 amplified a 477 bp long cDNA fragment (Figure 1B). Nested PCR with the primer combinations KAT6A-3582F1/LEUTX-301R1 and KAT6A3582F1/LEUTX-157R1 amplified 433 and 288 bp long cDNA fragments, respectively (Figure 1C). Direct sequencing of the nested PCR products showed that both were KAT6A-LEUTX chimeric cDNA fragments in which exon 16 of KAT6A (nucleotide 3764 in sequence with accession number NM_006766.5) was fused in frame to exon 2 of LEUTX (nucleotide 75 in sequence with accession number NM_001382345.1) (Figure 1D).

\section{Discussion}

To the best of our knowledge, the present case is the second therapy-related AML and the third AML overall in which both the translocation $\mathrm{t}(8 ; 19)(\mathrm{p} 11 ; \mathrm{q} 13)$ and the resulting KAT6A-LEUTX fusion are reported [ $(2,5)$, present study]. All three AMLs have the same fusion transcript in which exon 16 of KAT6A (nucleotide 3764 in sequence with accession number NM_006766.5) is fused in frame to exon 2 of LEUTX (nucleotide 75 in sequence with accession number NM_001382345.1).

The KAT6A gene together with its paralog KAT6B on 10q22 (also known as MORF, MOZ2, and MYST4), KAT5 on $11 \mathrm{q} 13$ (also known as TIP60), KAT7 on 17q21 (also known as $H B O 1$ and MYST2), and KAT8 on 16p11 (also known as $M O F$ and MYST1) code for proteins that compose the MYST family of histone acetyltransferases (16-18). These proteins share a highly conserved MYST domain consisting of the Acetyl-CoA-binding motif and a plant homeodomain (PHD)type zinc finger domain (17-20). KAT6A and KAT6B acetyltransferases acylate both histone $\mathrm{H} 3$ and non-histone proteins, play important roles in many cellular activities, such as regulation of transcription, signal transduction, chromatin organization and cell differentiation, and regulate various biological processes such as hematopoiesis, neurogenesis, skeletogenesis, and craniofacial as well as heart development $(17,21,22)$.

The first 810 amino acids of the KAT6A protein contain a nuclear localization domain, two PHD zinc finger domains, a histone acetyl-transferase domain, regions which interact with the proteins runt-related transcription factor 1 (RUNX1), promyelocytic leukemia protein (PML) and bromodomain and PHD finger containing 1 (BRPF1), and many phosphorylation and acetylation sites (Figure 2). The other part of the KAT6A protein (amino acids 1001-2004) contains a region which interacts with both RUNX1 and PML proteins and a region which is required for activation of RUNX1 (Figure 2) (see reference sequence NP_006757.2; https://www.ncbi.nlm.nih.gov/protein/NP_006757.2).

LEUTX is a paired (PRD)-like homeobox protein implicated in embryogenesis. Its expression is restricted to the 4-cell to 8-cell stage of the preimplantation embryo where it is one of the regulators of embryonic genome activation (23-25). LEUTX is not expressed in any other cell type including human embryonic stem cells $(24,25)$. It has three sites, which are required for binding to the 5'-TAATCC-3' sequence, and four nine-amino-acid transactivation domains (9aaTAD) (see reference sequence NP_001369274.1; https://www.ncbi.nlm.nih.gov/protein/NP_001369274.1).

A major consequence of $\mathrm{t}(8 ; 19)(\mathrm{p} 11 ; \mathrm{q} 13)$ is expression of the LEUTX gene in the leukemic cells. The ensuing 1313 amino acids long KAT6A-LEUTX chimeric protein is composed of the first 1117 amino acids from KAT6A (reference sequence NP_006757.2) and almost the entire LEUTX protein (reference sequence NP_001369274.1; only the first two amino acids were missing). KAT6A-LEUTX is predicted to have a dual function: its KAT6A amino-terminal part acylates both histone $\mathrm{H} 3$ and non-histone proteins, whereas its LEUTX carboxy-terminal part binds to a $36 \mathrm{bp}$ DNA element containing a 5'-TAATCC-3' sequence motif in the promoters of the target gene and, through the four 9aaTAD, activates transcription (22, 24-26). Abnormal expression of homeobox genes has been reported in various types of neoplasia including leukemias (27-32). Ectopic expression of the caudal-type homeobox gene $C D X 2$ or expression of various NUP98-HOX fusion genes has induced AML in mice $(33,34)$. Thus, the involvement of the KAT6A-LEUTX fusion gene in leukemogenesis seems well established.

Apart from the KAT6A-LEUTX fusion, KAT6A is known to fuse, as a 5'-end partner, to the CREB binding protein $(C R E B B P)$ gene and E1A binding protein p300 gene (EP300) in AML carrying the chromosome translocations $\mathrm{t}(8 ; 16)(\mathrm{p} 11 ; \mathrm{p} 13)$ and $\mathrm{t}(8 ; 22)(\mathrm{p} 11 ; \mathrm{q} 13)$, respectively (35-38). CREBBP and EP300 are lysine acetyltransferases with many cellular functions $(39,40)$. In addition, KAT6A also fuses, again as a 5 '-end fusion partner, with the nuclear receptor coactivator 2 (NCOA2) and nuclear receptor coactivator 3 (NCOA3) genes 

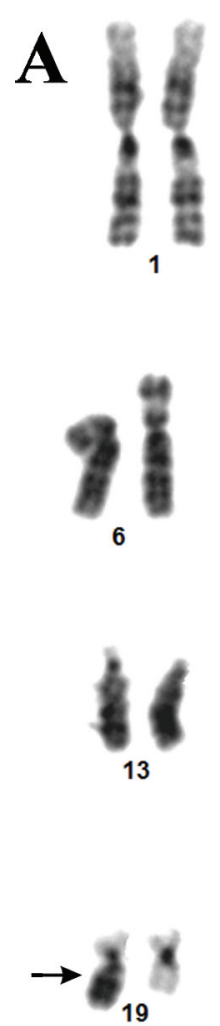

9

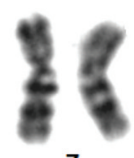

7

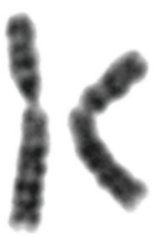

2
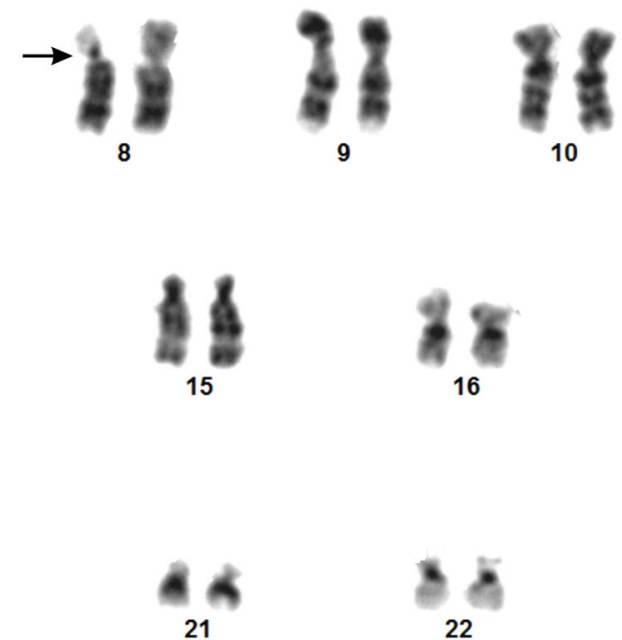

10
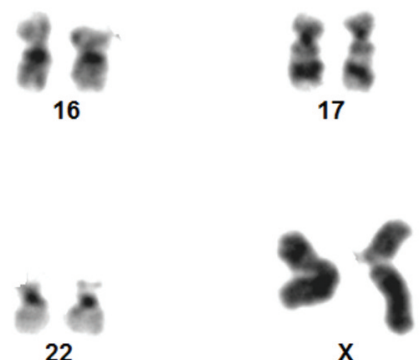

X

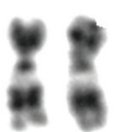

11

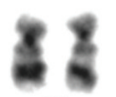

17

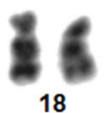

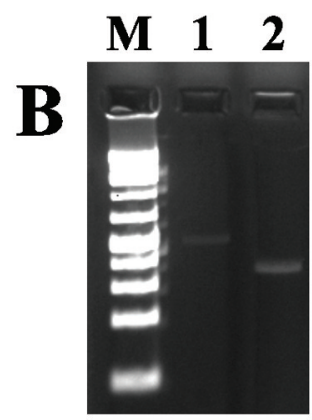

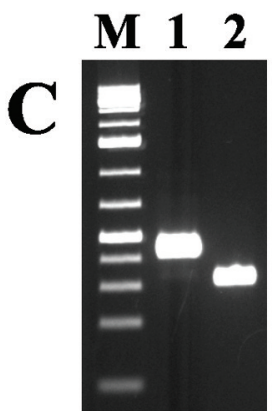

\section{D \\ $K A T 6 A$ exon 16 \\ A $\mathrm{AG}$ T CA G AT GATG C T G AT GIAG G G C CA AGG C G T TAT C G T}

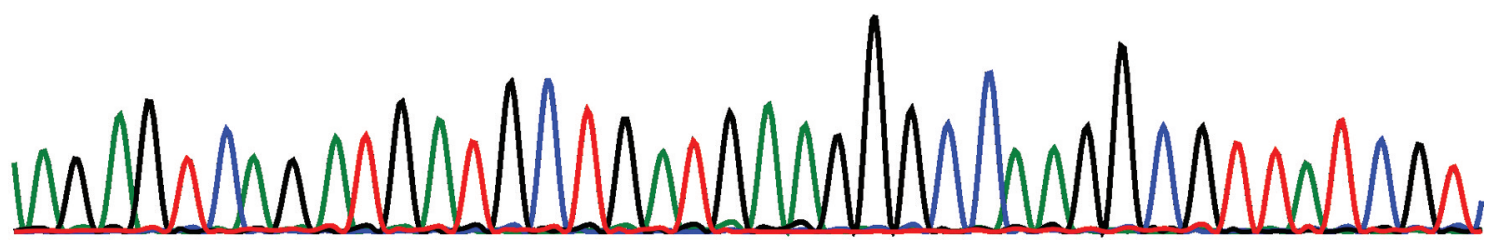

Figure 1. Examination by G-banding analysis, reverse transcription polymerase chain reaction (RT-PCR), and Sanger sequencing of the therapyrelated acute myeloid leukemia (AML). A) Karyogram showing the der(8)t(8;19)(p11.2;q13.3) and der(19)t(8;19)(p11.2;q13.3). Breakpoints are indicated by arrows. B) Gel electrophoresis showing the amplified KAT6A-LEUTX cDNA fragments using the outer primer combination KAT6A3558F1/LEUTX-320R1 (lane 1) and the amplified control ABL1 cDNA fragment using the ABL1-91F1/ABL1-404R1 primer combination (lane 2). C) Gel electrophoresis showing the amplified KAT6A-LEUTX cDNA fragments with nested PCR using the primer combinations KAT6A3582F1/LEUTX-301R1 (lane 1) and KAT6A-3582F1/LEUTX-157R1 (lane 2). M: GeneRuler 1 Kb Plus DNA ladder (ThermoFisher Scientific). D) Partial sequence chromatograms of the cDNA amplified fragment showing the junction between exons 16 of KAT6A and 2 of LEUTX. 


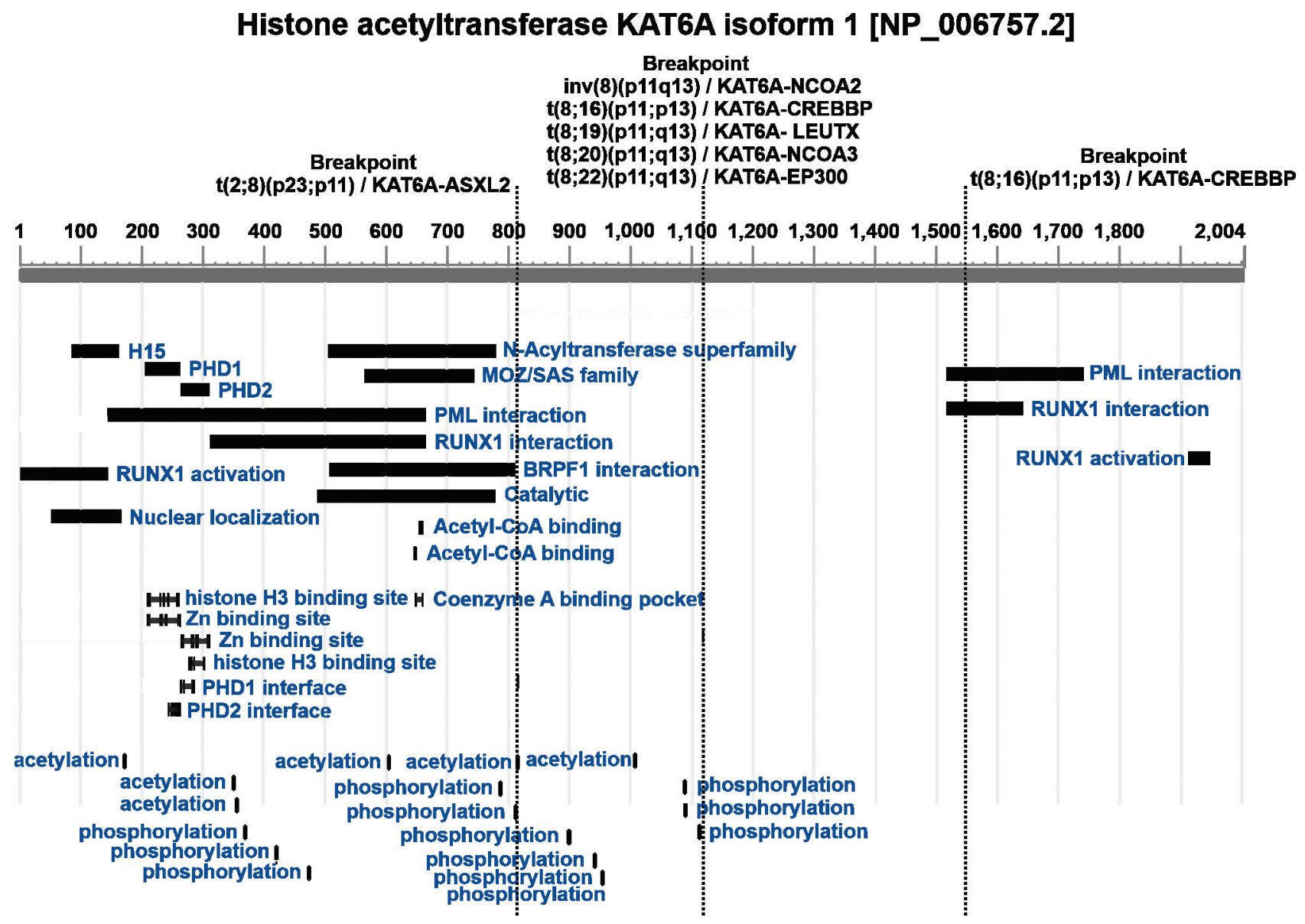

\section{Paired-like homeodomain transcription factor LEUTX isoform 1 [NP_001369274.1]}

Breakpoint $t(8 ; 19)(p 11 ; q 13) /$ KAT6A- LEUTX

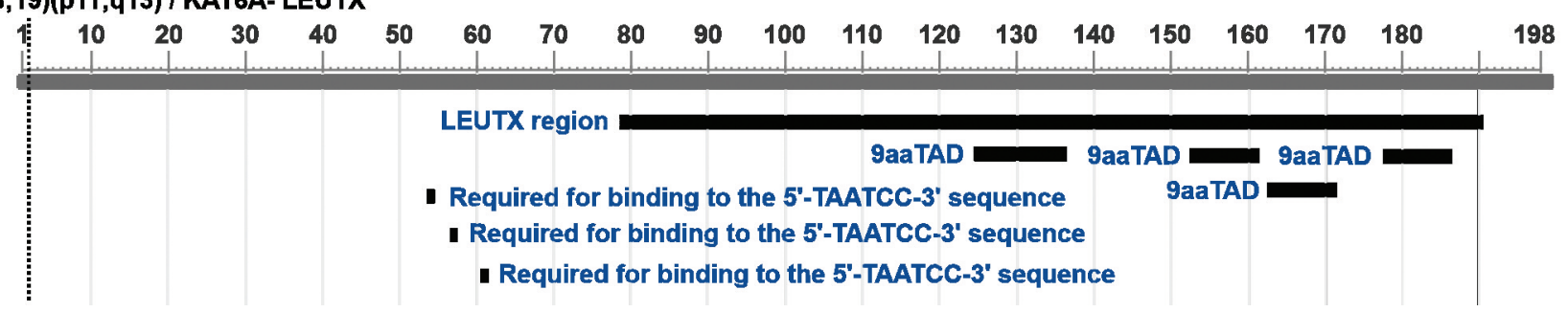

Figure 2. The proteins histone lysine acetyltransferase 6A (KAT6A) isoform 1(accession number NP_006757.2) and leucine twenty homeobox (LEUTX) isoform 1 (accession number NP_001369274.1). All known regions and sites are shown. Vertical dotted lines show the breakpoints in the various translocations.

in AML with inv(8)(p11q13) and $\mathrm{t}(8 ; 20)(\mathrm{p} 11 ; \mathrm{q} 13)$, respectively (41-44). The proteins NCOA2 and NCOA3 are members of the p160/steroid receptor coactivator family that mediate the transcriptional functions of nuclear receptors and other transcription factors (45-47). In a pediatric therapy-related myelodysplastic syndrome with $\mathrm{t}(2 ; 8)(\mathrm{p} 23 ; \mathrm{p} 11)$, KAT6A was fused to the ASXL transcriptional regulator 2 gene (ASXL2), which codes for a protein member of additional sex combs-like protein (ASXL) family (48-50) (for KAT6A-ASXL2 fusion, see sequences with accession numbers $\mathrm{AB} 084281.1$ and BAD00088.1 in the National Center for Biotechnology Information database). The members of the ASXL family are epigenetic scaffolding proteins that assemble epigenetic regulators and transcription factors to specific genomic loci 
with histone modifications (51-53). In a similar way to KAT6A-LEUTX, all the above-mentioned chimeric proteins retain the amino-terminal-KAT6A moiety, which contains the nuclear localization signal, two PHD zinc fingers, and the histone acetyl-transferase domain, the regions which interact with RUNX1, PML, and BRPF1 proteins, as well as the phosphorylation and acetylation sites. They lack the carboxyl terminal moiety of KAT6A, which interacts with RUNX1 and PML proteins, and also a region which is required for activation of RUNX1 (Figure 2).

Thus, a chimeric protein containing an amino-terminal part acylating both histone $\mathrm{H} 3$ and non-histone proteins, and a carboxy terminal regulating transcription, come across as a common theme whenever KAT6A-fusion genes occur in hematologic malignancies.

\section{Conflicts of Interest}

The Authors declare that they have no potential conflicts of interest in this study.

\section{Authors' Contributions}

IP designed and supervised the experiments, performed molecular genetic experiments, evaluated the data, and drafted the manuscript. KA performed cytogenetic and molecular experiments, and evaluated the data. LFR made clinical evaluations and treated the patient. IMI performed diagnostic flow cytometry. FM evaluated the cytogenetic data. SH evaluated the data and assisted with writing of the manuscript. All Authors read and approved the final manuscript.

\section{Acknowledgements}

This work was supported by grants from Radiumhospitalets Legater.

\section{References}

1 Brizard A, Guilhot F, Huret JL, Benz-Lemoine E and Tanzer J: The 8p11 anomaly in "monoblastic" leukaemia. Leuk Res 12(8): 693697, 1988. PMID: 3184987. DOI: 10.1016/0145-2126(88)90105-1

2 Chinen Y, Taki T, Tsutsumi Y, Kobayashi S, Matsumoto Y, Sakamoto N, Kuroda J, Horiike S, Nishida K, Ohno H, Uike N and Taniwaki M: The leucine twenty homeobox (LEUTX) gene, which lacks a histone acetyltransferase domain, is fused to KAT6A in therapy-related acute myeloid leukemia with t(8;19)(p11;q13). Genes Chromosomes Cancer 53(4): 299-308, 2014. PMID: 24446090. DOI: $10.1002 / \mathrm{gcc} .22140$

3 Eason AC, Bunting ST, Peterson JF, Saxe D and Sabnis HS: Acute myeloid leukemia in an infant with $t(8 ; 19)(p 11.2 ; q 13)$ translocation: Case report and a review of the literature. Case Rep Hematol 2019: 4198415, 2019. PMID: 31583141. DOI: $10.1155 / 2019 / 4198415$

4 Gervais C, Murati A, Helias C, Struski S, Eischen A, Lippert E, Tigaud I, Penther D, Bastard C, Mugneret F, Poppe B, Speleman F, Talmant P, VanDen Akker J, Baranger L, Barin C, Luquet I, Nadal N, Nguyen-Khac F, Maarek O, Herens C, Sainty D, Flandrin G, Birnbaum D, Mozziconacci MJ, Lessard M and Groupe
Francophone de Cytogénétique Hématologique.: Acute myeloid leukaemia with 8p11 (MYST3) rearrangement: An integrated cytologic, cytogenetic and molecular study by the groupe francophone de cytogénétique hématologique. Leukemia 22(8): 1567-1575, 2008. PMID: 18528428. DOI: 10.1038/leu.2008.128

5 Sramkova L, Cermakova J, Kutkova K, Zemanova Z, Pavlicek P, Zuna J, Stary J and Zaliova M: Rapidly progressing acute myeloid leukemia with KAT6A-LEUTX fusion in a newborn. Pediatr Blood Cancer 67(10): e28663, 2020. PMID: 32779858. DOI: $10.1002 / \mathrm{pbc} .28663$

6 Stark B, Resnitzky P, Jeison M, Luria D, Blau O, Avigad S, Shaft D, Kodman Y, Gobuzov R and Ash S: A distinct subtype of M4/M5 acute myeloblastic leukemia (AML) associated with $\mathrm{t}(8: 16)(\mathrm{p} 11: \mathrm{p} 13)$, in a patient with the variant $\mathrm{t}(8: 19)(\mathrm{p} 11: \mathrm{q} 13)-$ case report and review of the literature. Leuk Res 19(6): 367-379, 1995. PMID: 7596149. DOI: 10.1016/0145-2126(94)00150-9

7 Tanzer J, Brizard A, Guilhot F, Benz-Lemoine E, Dreyfus B, Lessard M, Herchkovitch C, Mossafa H, Davi F and Huret J: [Acute leukemia with translocation $(8 ; 16)$ ]. Nouv Rev Fr Hematol 30(1-2): 83-87, 1988. PMID: 3290841.

8 Swerdlow SH, Campo E, Harris NL, Jaffe ES, Pileri SA, Stein H and Thiele J: WHO classification of tumours of haematopoietic and lymphoid tissues (Revised 4th edition). 1ARC: Lyon, 2017.

9 Czepulkowski B: Basic techniques for the preparation and analysis of chromosomes from bone marrow and leukaemic blood. In: Human cytogenetics: malignancy and acquired abnormalities. Rooney DE (ed.). Oxford University Press: New York, pp. 1-26, 2001.

10 McGowan-Jordan J, Simons A and Schmid M: ISCN 2016: An international system for human cytogenomic nomenclature Karger: Basel, pp. 140, 2016.

11 Torkildsen S, Brunetti M, Gorunova L, Spetalen S, Beiske K, Heim S and Panagopoulos I: Rearrangement of the chromatin organizer special at-rich binding protein 1 gene, SATB1, resulting from a $\mathrm{t}(3 ; 5)(\mathrm{p} 24 ; \mathrm{q} 14)$ chromosomal translocation in acute myeloid leukemia. Anticancer Res 37(2): 693-698, 2017. PMID: 28179318. DOI: 10.21873/anticanres.11365

12 Singhal H, Ren YR and Kern SE: Improved DNA electrophoresis in conditions favoring polyborates and lewis acid complexation. PLoS One 5(6): e11318, 2010. PMID: 20593002. DOI: 10.1371 /journal.pone.0011318

13 Altschul SF, Gish W, Miller W, Myers EW and Lipman DJ: Basic local alignment search tool. J Mol Biol 215(3): 403-410, 1990. PMID: 2231712. DOI: 10.1016/S0022-2836(05)80360-2

14 Kent WJ: BLAT - the BLAST-like alignment tool. Genome Res 12(4): 656-664, 2002. PMID: 11932250. DOI: 10.1101/gr.229202

15 Kent WJ, Sugnet CW, Furey TS, Roskin KM, Pringle TH, Zahler $\mathrm{AM}$ and Haussler D: The human genome browser at UCSC. Genome Res 12(6): 996-1006, 2002. PMID: 12045153. DOI: $10.1101 /$ gr.229102

16 Avvakumov $\mathrm{N}$ and Côté J: The MYST family of histone acetyltransferases and their intimate links to cancer. Oncogene 26(37): 5395-5407, 2007. PMID: 17694081. DOI: 10.1038/ sj.onc. 1210608

17 Sapountzi V and Côté J: MYST-family histone acetyltransferases: beyond chromatin. Cell Mol Life Sci 68(7): 1147-1156, 2011. PMID: 21132344. DOI: 10.1007/s00018-010-0599-9

18 Utley RT and Côté J: The MYST family of histone acetyltransferases. Curr Top Microbiol Immunol 274: 203-236, 2003. PMID: 12596909. DOI: 10.1007/978-3-642-55747-7_8 
19 Avvakumov N and Côté J: Functions of myst family histone acetyltransferases and their link to disease. Subcell Biochem 41: 295-317, 2007. PMID: 17484133

20 Thomas $\mathrm{T}$ and Voss AK: The diverse biological roles of MYST histone acetyltransferase family proteins. Cell Cycle 6(6): 696704, 2007. PMID: 17374998. DOI: 10.4161/cc.6.6.4013

21 Perez-Campo FM, Costa G, Lie-a-Ling M, Kouskoff V and Lacaud G: The MYSTerious MOZ, a histone acetyltransferase with a key role in haematopoiesis. Immunology 139(2): 161-165, 2013. PMID: 23347099. DOI: 10.1111/imm.12072

22 Wiesel-Motiuk N and Assaraf YG: The key roles of the lysine acetyltransferases KAT6A and KAT6B in physiology and pathology. Drug Resist Updat 53: 100729, 2020. PMID: 33130515. DOI: $10.1016 /$ j.drup.2020.100729

23 Töhönen V, Katayama S, Vesterlund L, Jouhilahti EM, Sheikhi M, Madissoon E, Filippini-Cattaneo G, Jaconi M, Johnsson A, Bürglin TR, Linnarsson S, Hovatta O and Kere J: Novel PRDlike homeodomain transcription factors and retrotransposon elements in early human development. Nat Commun 6: 8207, 2015. PMID: 26360614. DOI: 10.1038/ncomms9207

24 Jouhilahti EM, Madissoon E, Vesterlund L, Töhönen V, Krjutškov K, Plaza Reyes A, Petropoulos S, Månsson R, Linnarsson S, Bürglin T, Lanner F, Hovatta O, Katayama S and Kere J: The human PRD-like homeobox gene LEUTX has a central role in embryo genome activation. Development 143(19): 3459-3469, 2016. PMID: 27578796. DOI: 10.1242/dev.134510

25 Katayama S, Ranga V, Jouhilahti EM, Airenne TT, Johnson MS, Mukherjee K, Bürglin TR and Kere J: Phylogenetic and mutational analyses of human LEUTX, a homeobox gene implicated in embryogenesis. Sci Rep 8(1): 17421, 2018. PMID: 30479355. DOI: 10.1038/s41598-018-35547-5

26 Yang XJ: MOZ and MORF acetyltransferases: Molecular interaction, animal development and human disease. Biochim Biophys Acta 1853(8): 1818-1826, 2015. PMID: 25920810. DOI: $10.1016 /$ j.bbamcr.2015.04.014

27 Rawat VP, Humphries RK and Buske C: Beyond Hox: The role of ParaHox genes in normal and malignant hematopoiesis. Blood 120(3): 519-527, 2012. PMID: 22547580. DOI: 10.1182/blood2012-02-385898

28 Alharbi RA, Pettengell R, Pandha HS and Morgan R: The role of HOX genes in normal hematopoiesis and acute leukemia. Leukemia 27(5): 1000-1008, 2013. PMID: 23212154. DOI: 10.1038/leu.2012.356

29 Bhatlekar S, Fields JZ and Boman BM: HOX genes and their role in the development of human cancers. J Mol Med (Berl) 92(8): 811-823, 2014. PMID: 24996520. DOI: 10.1007/s00109014-1181-y

30 De Braekeleer E, Douet-Guilbert N, Basinko A, Le Bris MJ, Morel F and De Braekeleer M: Hox gene dysregulation in acute myeloid leukemia. Future Oncol 10(3): 475-495, 2014. PMID: 24559452. DOI: $10.2217 /$ fon. 13.195

31 Collins EM and Thompson A: HOX genes in normal, engineered and malignant hematopoiesis. Int J Dev Biol 62(11-12): 847-856, 2018. PMID: 30604854. DOI: 10.1387/ijdb.180206at

32 Nagel S and Drexler HG: Deregulated NKL homeobox genes in B-cell lymphoma. Cancers (Basel) 11(12): 2019. PMID: 31779217. DOI: $10.3390 /$ cancers 11121874

33 Rawat VP, Cusan M, Deshpande A, Hiddemann W, QuintanillaMartinez L, Humphries RK, Bohlander SK, Feuring-Buske M and Buske C: Ectopic expression of the homeobox gene $\mathrm{Cdx} 2$ is the transforming event in a mouse model of $\mathrm{t}(12 ; 13)(\mathrm{p} 13 ; \mathrm{q} 12)$ acute myeloid leukemia. Proc Natl Acad Sci USA 101(3): 817822, 2004. PMID: 14718672. DOI: 10.1073/pnas.0305555101

34 Gough SM, Slape CI and Aplan PD: NUP98 gene fusions and hematopoietic malignancies: Common themes and new biologic insights. Blood 118(24): 6247-6257, 2011. PMID: 21948299. DOI: 10.1182/blood-2011-07-328880

35 Borrow J, Stanton VP Jr, Andresen JM, Becher R, Behm FG, Chaganti RS, Civin CI, Disteche C, Dubé I, Frischauf AM, Horsman D, Mitelman F, Volinia S, Watmore AE and Housman DE: The translocation $\mathrm{t}(8 ; 16)(\mathrm{p} 11 ; \mathrm{p} 13)$ of acute myeloid leukaemia fuses a putative acetyltransferase to the CREB-binding protein. Nat Genet 14(1): 33-41, 1996. PMID: 8782817. DOI: 10.1038/ng0996-33

36 Panagopoulos I, Isaksson M, Lindvall C, Björkholm M, Ahlgren T, Fioretos T, Heim S, Mitelman F and Johansson B: RT-PCR analysis of the MOZ-CBP and CBP-MOZ chimeric transcripts in acute myeloid leukemias with $\mathrm{t}(8 ; 16)(\mathrm{p} 11 ; \mathrm{p} 13)$. Genes Chromosomes Cancer 28(4): 415-424, 2000. PMID: 10862050. DOI: 10.1002/1098-2264(200008)28:4<415::aid-gcc7>3.0.co;2-i

37 Chaffanet M, Gressin L, Preudhomme C, Soenen-Cornu V, Birnbaum D and Pébusque MJ: MOZ is fused to p300 in an acute monocytic leukemia with $\mathrm{t}(8 ; 22)$. Genes Chromosomes Cancer 28(2): 138-144, 2000. PMID: 10824998. DOI: 10.1002/ (sici)1098-2264(200006)28:2<138::aid-gcc2>3.0.co;2-2

38 Kitabayashi I, Aikawa Y, Yokoyama A, Hosoda F, Nagai M, Kakazu N, Abe T and Ohki M: Fusion of MOZ and p300 histone acetyltransferases in acute monocytic leukemia with a $\mathrm{t}(8 ; 22)(\mathrm{p} 11 ; \mathrm{q} 13)$ chromosome translocation. Leukemia 15(1): 89-94, 2001. PMID: 11243405. DOI: 10.1038/sj.leu.2401983

39 Dancy BM and Cole PA: Protein lysine acetylation by p300/CBP. Chem Rev 115(6): 2419-2452, 2015. PMID: 25594381. DOI: $10.1021 / \mathrm{cr} 500452 \mathrm{k}$

40 Attar N and Kurdistani SK: Exploitation of EP300 and CREBBP lysine acetyltransferases by cancer. Cold Spring Harb Perspect Med 7(3): 2017. PMID: 27881443. DOI: 10.1101/cshperspect. a026534

41 Liang J, Prouty L, Williams BJ, Dayton MA and Blanchard KL: Acute mixed lineage leukemia with an inv(8)(p11q13) resulting in fusion of the genes for MOZ and TIF2. Blood 92(6): 21182122, 1998. PMID: 9731070.

42 Carapeti M, Aguiar RC, Goldman JM and Cross NC: A novel fusion between MOZ and the nuclear receptor coactivator TIF2 in acute myeloid leukemia. Blood 91(9): 3127-3133, 1998. PMID: 9558366.

43 Carapeti M, Aguiar RC, Watmore AE, Goldman JM and Cross NC: Consistent fusion of MOZ and TIF2 in AML with inv(8)(p11q13). Cancer Genet Cytogenet 113(1): 70-72, 1999. PMID: 10459350. DOI: 10.1016/s0165-4608(99)00007-2

44 Esteyries S, Perot C, Adelaide J, Imbert M, Lagarde A, Pautas C, Olschwang S, Birnbaum D, Chaffanet $\mathrm{M}$ and Mozziconacci MJ: NCOA3, a new fusion partner for MOZ/MYST3 in M5 acute myeloid leukemia. Leukemia 22(3): 663-665, 2008. PMID: 17805331. DOI: $10.1038 /$ sj.leu.2404930

45 York B and O'Malley BW: Steroid receptor coactivator (SRC) family: Masters of systems biology. J Biol Chem 285(50): 3874338750, 2010. PMID: 20956538. DOI: 10.1074/jbc.R110.193367

46 Dasgupta S, Lonard DM and O'Malley BW: Nuclear receptor coactivators: Master regulators of human health and disease. Annu Rev Med 65: 279-292, 2014. PMID: 24111892. DOI: 10.1146/annurev-med-051812-145316 
47 Szwarc MM, Kommagani R, Lessey BA and Lydon JP: The p160/steroid receptor coactivator family: potent arbiters of uterine physiology and dysfunction. Biol Reprod 91(5): 122, 2014. PMID: 25297546. DOI: 10.1095/biolreprod.114.125021

48 Imamura T, Kakazu N, Hibi S, Morimoto A, Fukushima Y, Ijuin I, Hada S, Kitabayashi I, Abe T and Imashuku S: Rearrangement of the MOZ gene in pediatric therapy-related myelodysplastic syndrome with a novel chromosomal translocation $\mathrm{t}(2 ; 8)(\mathrm{p} 23 ; \mathrm{p} 11)$. Genes Chromosomes Cancer 36(4): 413-419, 2003. PMID: 12619166. DOI: $10.1002 / \mathrm{gcc} .10172$

49 Katoh $\mathrm{M}$ and Katoh M: Identification and characterization of ASXL2 gene in silico. Int J Oncol 23(3): 845-850, 2003. PMID: 12888926

50 Katoh M and Katoh M: Identification and characterization of ASXL3 gene in silico. Int J Oncol 24(6): 1617-1622, 2004. PMID: 15138607.
51 Katoh M: Functional and cancer genomics of ASXL family members. Br J Cancer 109(2): 299-306, 2013. PMID: 23736028. DOI: $10.1038 /$ bjc.2013.281

52 Russell B and Graham JM Jr: Expanding our knowledge of conditions associated with the ASXL gene family. Genome Med 5(2): 16, 2013. PMID: 23672984. DOI: 10.1186/gm420

53 Micol JB and Abdel-Wahab O: The role of additional sex combslike proteins in cancer. Cold Spring Harb Perspect Med 6(10): 2016. PMID: 27527698. DOI: 10.1101/cshperspect.a026526

Received February 3, 2021

Revised February 22, 2021

Accepted February 23, 2021 